\title{
The Impact of Tick Size Reduction on Liquidity and Order Strategy: Evidence from the Jakarta Stock Exchange (JSX)
}

\author{
Irwan Adi Ekaputra*, Basharat Ahmad*
}

\begin{abstract}
On January 3, 2005, the Jakarta Stock Exchange (JSX) implemented a new tick size of Rp10 in addition to the existing Rp5, Rp25, and Rp50 tick sizes. This new tick size affects shares within Rp500-Rp2000 price range, for these shares were previously traded with Rp25 tick size. The main purpose of adding this new tick size is to boost liquidity, especially for shares within the aforementioned range. Using daily data, $t$-tests, and cross-sectional multiple regressions, this study finds the new policy significantly reduces relative bid-ask spread, but also lessens bid and ask depth. From the aspects of width and immediacy cost, stock liquidity is enhanced; but from the viewpoint of bid and ask depth, stock liquidity is diminished. To resolve the two contradictory results, we use the ratio of average depth to relative spread (DRS). The new tick size does not trim down DRS significantly, or it does not diminish total liquidity. Furthermore, with smaller relative spread, our findings confirm traders' tendency to change their strategy from using limit orders to market orders, and to split their orders into smaller quantities.
\end{abstract}

Keywords: Jakarta Stock Exchange, market microstructure, tick size, liquidity, bid-ask spread

JEL Classification: G14, G15, G18

*We would like to thank Mohamed Ariff, Professor of Finance, Monash University, for his valuable inputs during the presentation of this paper at The $1^{\text {st }}$ International Conference on Business and Management Research (ICBMR), in Bali, August 2006. 


\section{INTRODUCTION}

The Jakarta Stock Exchange (JSX) is a computerized order driven market, operating a system known as JATS (Jakarta Automated Trading System) which was first implemented on May 22, 1995. On January 3, 2005, the JSX added a new tick size of Rp10 affecting shares within Rp500-Rp2000 price range. These shares were previously traded using Rp25 tick. The JSX board of directors argued that, besides enhancing JSX revenue, the main purpose of adding this new tick size is to increase liquidity, especially for shares within the affected price range.

The effectiveness of tick size reduction on improving liquidity is still inconclusive. The proponents of the policy argue that the reduction will benefit liquidity seekers because eventually the spread will decline. On the contrary, the critics claim that the decrease in spread will induce traders to use market orders instead of limit orders. Consequently the market depth, market transparency, and trade volume will diminish.

This paper investigates the impact of January 3, 2005 tick size reduction on: (1) stock liquidity, (2) traders order strategy, namely the tendency to use limit orders or market orders, and (3) traders average order size. Following Harris (2003), stock liquidity is defined as the stock ability to be traded in large quantities quickly, cheaply, and without impacting its price. Liquidity is construed as having four dimensions: (1) width, (2) immediacy, (3) depth, and (4) resiliency.

Similar to Purwoto and Tandelilin (2004), liquidity is measured using end of day bid-ask spread and bid-ask depth. However, their studies were conducted around the July 3, 2000 implementation of a single Rp5 market wide tick size.

\section{PREVIOUS STUDIES}

Harris (1994) was the first to investigate the impact of tick size reduction. He argued that tick size reduction will likely reduce bid-ask spread (lower transaction cost), and improve trade volume. On the other hand, if the tick size is too small, time priority rule will be ignored because of quote-matcher or front-runner problem. Quote-matchers will take advantage of large open orders position. They will try to place slightly better orders in front of the queued orders, which will be more profitable if the tick size is small. To protect themselves, informed traders will divide their orders into smaller quantities. Hence, they change from limit orders to market orders, and this change of strategy will decrease market depth. 
A study by Ahn, Chao, and Choe (1996) found that tick size reduction in the American Stock Exchange in September 1992 diminished bid-ask spread, but did not increase transaction volume. Bacidore (1997) found that March 1997 tick size reduction in the Toronto Stock Exchange also reduced bid-ask spread and market depth, but trade activity did not change significantly. Bessembinder's study (2000) indicated that tick size reduction in NASDAQ lowered bid-ask spread and volatility. A study by Goldstein and Kavajecz (2000) found declining bid-ask spread and market depth, following tick size reduction in the New York Stock Exchange in June 1997. Lau and McInish (1995) found that tick size reduction in Singapore stock exchange in July 1994 reduced bid-ask spread. Bacidore et al. (2003) found that tick size reduction in the NYSE in 2000 caused traders to reduce their order size, to hide some orders, and to cancel their limit orders more frequently. Bourghelle and Declerck (2004) found positive convex relationships between tick size and relative spread in the Paris Bourse.

Subsequent to July 3, 2000 tick size reduction in the JSX, Atmoko (2001), and Purwoto and Tandelilin (2004) conducted comparable research in this area. Atmoko (2001) found that tick size reduction is effective for reducing market spread for stocks below Rp500. Purwoto and Tandelilin (2004) found both market spread and market depth dropped significantly after the JSX implemented a single Rp5 tick size for all stocks.

\section{Data and Methodology}

This research utilizes the JSX stocks daily data from November 2, 2004 until February 28, 2005, with the event date on January 3, 2005. Since November 2, 2004 until December 30, 2004 (subperiod 1) stocks within the Rp500 to Rp2000 were traded with Rp25 tick, but from January 4, 2005 to February 28, 2005 (subperiod 2), these stocks were traded with the new Rp10 tick.

We only observe stocks listed on the main board and priced between Rp500 to Rp2000, for they are the ones affected by the new policy. To be included in the sample, stocks must meet the following criteria:

1. Closing price between Rp500-Rp2000 as of December 30, 2004.

2. The stock was traded at least once, during each subperiod.

3. The stock was not delisted nor split during the period.

4. The stock did not disburse any stock dividend nor issue rights during the period. 
Using the said criteria, 24 stocks were selected as the sample, representing 83 per cent of the total trade value of all stocks within Rp500 to Rp2000 price band (as of December 30, 2004).

We employ the t-test to study mean difference in two related samples (each subperiod is considered as one sample). In addition, we also use cross-sectional multiple regression to test the effect of tick size reduction on liquidity, while controlling other factors affecting liquidity as documented by previous research.

\section{RESULTS AND DISCUSSIONS}

\subsection{Bid-Ask Spread}

One common measure of stock liquidity is its relative bid-ask spread (relative spread). Relative spread is used more often than nominal spread since it does not contain any currency unit, and it will be easier to compare between stocks and international markets with different currencies. The formula to calculate relative spread is presented in equation (1):

$$
\text { Relative Spread }{ }_{j, t}=\frac{A_{j, t}-B_{j, t}}{\left(A_{j, t}+B_{j, t}\right) / 2}
$$

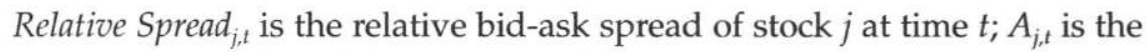
best ask price of stock $j$ at time $t$; and $B_{j, t}$ is the best bid price of stock $j$ at time $t$.

Table 1 shows the average relative spread of each stock in each subperiod. Before the new tick size, the average relative spread was 2.90 per cent, while after the new policy, the average relative spread plummeted to 1.16 per cent; or the average relative spread is 1.74 per cent lower after the tick size reduction. To statistically test the mean difference before and after the tick size reduction, we use the t-test. The result of this test confirms that the mean of the relative spread is significantly lower after the tick size reduction (Table 2).

The reduction of relative spread means immediacy costs and transaction costs are lower after the tick size reduction. Based on immediacy and width dimensions of liquidity, lower spread means higher stock liquidity. If the relative spread is lower, than it is cheaper for investors who are in a hurry to transact (need immediacy) to use market order, or to buy at the ask price or to sell at bid price. On the contrary, if the relative spread is higher, it will be more expensive for investors to 

Table 2

Average relative bid-ask spreads, before and after January 3, 2005 tick size reduction

\begin{tabular}{|c|c|c|}
\hline \multicolumn{2}{|c|}{ Average } & Average Change \\
Relative bid-ask spread & \\
\hline Before $^{\mathrm{a}}$ & After $^{\mathrm{b}}$ & \\
\hline $2.90 \%$ & $1.16 \%$ & $-1.74 \% * * *$ \\
\hline
\end{tabular}

${ }^{a}$ Average relative bid-ask spread before tick size reduction (2 November 2004 to 30 December 2004)

${ }^{\mathrm{b}}$ Average relative bid-ask spread after tick size reduction (4 January 2005 to 28 February 2005)

*** t-test result is significant at $1 \%$ level

\subsection{Bid and Ask Depth}

Another aspect of stock liquidity is its depth. A stock with higher depth is considered to be more liquid, because it could absorp a higher transaction value before affecting its price. Like the bid-ask data, one of the limitations of this study is that we only have end of day bid and ask depth (volume) data. In reality, bid-ask prices and volumes change continuously during trading hours.

Table 3

Averages of the best bid and ask depth, before and after January 3, 2005 tick size reduction

\begin{tabular}{|c|c|c|c|}
\hline & \multicolumn{2}{|c|}{$\begin{array}{l}\text { Average Volume } \\
\text { (in million of shares) }\end{array}$} & \multirow{2}{*}{$\begin{array}{l}\text { Average Change } \\
\text { (in million of } \\
\text { shares) }\end{array}$} \\
\hline & Before $^{a}$ & After $^{b}$ & \\
\hline Bid-Depth & 6.42 & 2.38 & $-4.04 * * *$ \\
\hline Ask-Depth & 6.87 & 2.10 & $-4.77 * * *$ \\
\hline
\end{tabular}

a Average volume (depth) before tick size reduction (2 November 2004 to 30 December 2004)

${ }^{\mathrm{b}}$ Average volume (depth) after tick size reduction (4 January 2005 to 28 February 2005)

*** t-test result is significant at $1 \%$ level 
After the new tick size is applied, as Table 3 shows, the average biddepth is 4.04 million shares or 69.2 per cent lower, and 22 of 24 stocks in the sample experience bid depth decline. Using t-test this reduction is significant at the one per cent level. Similarly, average ask depth after the new policy is 4.7 million shares or 69.4 per cent lower, and 23 of 24 stocks in the sample experiençe ask depth decline. Using t-test, this reduction is also significant at the one per cent level.

The decrease of both relative bid-ask spread and bid-ask depth give different signals on stock liquidity. A smaller relative spread means higher liquidity, but lower depth means lower liquidity. To settle these mix signals, we use the ratio of average depth to relative spreads.

\subsection{Depth to Relative Spread}

Harris (2003, p.394) explains stock liquidity as the ability to trade large quantities quickly, cheaply, without impacting its price. Relative bid-ask spread measures quickness or immediacy, and the transaction cost. Lower relative spread means higher liquidity because it represents lower costs to transact immediately. Meanwhile bid and ask depth or the average of the two, measures the ability to absorp large trade quantity. More depth implies better liquidity, since it represents higher capability to absorp large trade without inducing large price change.

Since the sign tests confirm diminishing relative spread and depth, the impact of tick size reduction on liquidity is ambiguous. To measure the trade-off between relative spread and depth, this study calculates the depth-to-relative spread ratio (DRS) (Purwoto and Tandelilin 2004) which is defined as:

$$
\text { Depth-to-RelativeSpread }(D R S)_{j, t}=\frac{\left(\text { Ask Depth }_{j, t}+\text { Bid Depth }_{j, t}\right) / 2}{\text { RelativeSpread }_{j, t}}
$$

Ask Depth $h_{j, t}$ is the best ask volume for stock $j$ at day. $t ;$ Bid Depth $h_{j, t}$ is the best bid volume for stock $j$ at day $t$; and Relative Spread $_{j, t}$ is stock $j$ relative bid-ask spread at day $t$. Intituitively this ratio measures whether the decrease of depth is larger or smaller than the decrease of relative spread. We use non-parametric sign test to check whether the change in DRS from before to after reduction period is significant, and the results are presented in Table 4.

After the new tick size, average DRS decreases 22,503,139 or 9.82 per cent. Diminishing DRS means the decrease in depth is larger than the decrease in relative spread. Even though the average of DRS decreases, 
the t-test does not reject the null hypotesis, implying that the decrease is not statistically significant. This result suggests that the JSX tick size reduction does not impair overall stock liquidity.

This result is different from what Purwoto and Tandelilin (2004) revealed from the single Rp5 tick size policy of July 3, 2000. The policy affected all stocks in the JSX, and caused the DRS liquidity to plummet significantly. Meanwhile, the January 3, 2005 policy involves only certain stocks between Rp500 and Rp2000, and thus generates a seemingly more benign impact on stock liquidity.

Table 4

Average of Depth to Spread (DRS),

before and after January 3, 2005 tick size reduction

\begin{tabular}{|c|c|c|}
\hline \multicolumn{2}{|c|}{ Average } & \multirow{2}{*}{ Average Change } \\
Depth-to-Spread (DRS) & \\
\hline Beforea & Afterb & $-22,503,139 \mathrm{C}$ \\
\hline $229,217,733$ & $206,714,594$ & \\
\hline
\end{tabular}

a. Average depth-to-spread before tick size reduction (2 November 2004 to 30 December 2004)

b Average depth-to-spread after tick size reduction (4 January 2005 to 28 February 2005)

c. t-test result is not statistically significant

\subsection{Multiple Regression Models}

The nonparametric tests show the tick size reduction leads to statistically significant lower relative bid-ask spread and bid-ask depth, but does not significantly reduce the ratio of average depth to relative spread. Based on previous studies such as Porter and Weaver (1997), Ronen and Weaver (1998), Purwoto and Tandelilin (2004), and also Ekaputra (2006), we discover the stock price, trade activity, and return volatility influence liquidity. Trade activity surrogates utilitarian traders' interests, or traders who are not primarily driven by profit; and return volatility represents the degree of market information asymmetry. To control these factors, and to study the impact of tick size reduction on both relative spread and depth to relative spread, we use the following multiple regression models: 
$\operatorname{LnRS}_{i}=\beta_{0}+\beta_{1}\left(\operatorname{LnPRICE}_{i}\right)+\beta_{2}\left(\operatorname{LnFREQ}_{i}\right)+\beta_{3}\left(\operatorname{LnVOLATILITY}_{i}\right)+$ $\beta_{4} D^{*} \operatorname{LnPRICE}_{i}+\beta_{5} D^{*} \operatorname{LnFREQ}_{i}+\beta_{6} D^{*} \operatorname{LnVOLATILITY}_{i}+\beta_{7} D+\varepsilon_{i}$

(3)

$$
\begin{aligned}
\operatorname{LnDRS}_{i}= & \beta_{0}+\beta_{1}\left(\operatorname{LnPRICE}_{i}\right)+\beta_{2}\left(\operatorname{LnFREQ}_{i}\right)+\beta_{3}\left(\operatorname{LnVOLATILITY}_{i}\right)+ \\
& \beta_{4} D^{*} \operatorname{LnPRICE}_{i}+\beta_{5} D^{*} \operatorname{LnFREQ}_{i}+\beta_{6} D^{*} \operatorname{LnVOLATILITY}_{i}+\beta_{7} D+\varepsilon_{i}
\end{aligned}
$$

(4)

In model (3) RS is the relative bid-ask spread, while in model (4) DRS is the average depth to relative bid-ask spread. For both models (3) and (4), PRICE is the average stock price, FREQ is the average trade frequency, VOLATILITY is the stock return volatility, and D is a dummy variable which is equal to zero for pre tick size reduction (subperiod 1), and is equal to 1 for post tick size reduction (subperiod 2).

The hypotheses for model (3) are:

$\mathrm{H} 1$ : Price will have a negative impact on relative spread.

H2: Frequency will have a negative impact on relative spread.

H3: Return volatility will have a positive impact on relative spread.

H4: Tick size reduction will affect the impact of price on relative spread

H5: Tick size reduction will affect the impact of trade frequency on relative spread

H6: Tick size reduction will affect the impact of return volatility on relative spread

H7: Tick size reduction will reduce the unconditional mean of relative spread

The hypotheses for model (4) are:

H1: Price will have an impact on depth to relative spread.

$\mathrm{H} 2$ : Frequency will have a positive impact on depth to relative spread.

H3: Return volatility will have a negative impact on depth to relative spread.

H4: Tick size reduction will affect the impact of price on depth to relative spread

H5: Tick size reduction will affect the impact of trade frequency on depth to relative spread 
Irwan Adj Ekaputra; Basharat Ahmad

H6: Tick size reduction will affect the impact of return volatility on depth to relative spread

H7: Tick size reduction will increase the unconditional mean of depth to relative spread

For both model (3) and (4), if the new tick size policy improves stock liquidity, we expect the data to support hypothesis number 7 (Hz). A summary of the expected signs of all regression coefficients are provided in Table 5, while the regression results are shown in Table 6.

Table 5

Expected signs of each coefficient in Model 3 and Model 4

\begin{tabular}{|l|c|c|c|}
\hline \multicolumn{1}{c|}{ Variable } & \multirow{2}{*}{ Coefficient } & Model 3 & Model 4 \\
\cline { 3 - 4 } & & Expected Sign & Expected Sign \\
\hline Intercept & $\beta_{0}$ & + & + \\
\hline Ln_PRICE & $\beta_{1}$ & - & $+/-$ \\
\hline Ln_VOLATILITY & $\beta_{2}$ & - & + \\
\hline Ln_FREQ & $\beta_{3}$ & + & - \\
\hline D*LN_PRICE & $\beta_{4}$ & $+/-$ & $+/-$ \\
\hline D*LN_VOLATILITY & $\beta_{5}$ & $+/-$ & $+/-$ \\
\hline D*LN_FREQ & $\beta_{6}$ & $+/-$ & $+/-$ \\
\hline D & $\beta_{7}$ & - & + \\
\hline
\end{tabular}

98 
The Impact of Tick Size Reduction on Liquidity and Order Strategy: Evidence from the Jakarta Stock Exchange (JSX)

Table 6

Regression results of Relative Spread and Depth to Relative Spread on price, volatility, frequency, and dummy variables

\begin{tabular}{|l|r|r|r|r|r|c|}
\hline \hline & \multicolumn{3}{|c|}{ Dependent Variable } & \multicolumn{3}{c|}{ Dependent Variable } \\
\cline { 2 - 7 } & \multicolumn{2}{|c|}{ Ln_Relative Spread } & \multicolumn{2}{c|}{ Ln_Depth to Relative Spread } \\
(Ln_DRS)
\end{tabular}

Based on Table 6, especially for the coefficient of dummy variable (D), we find the tick size reduction significantly decreases relative bid-ask spread (RS), but does not affect average depth to relative spread (DRS). The results are consistent with the t-tests conducted earlier. Hence, from the viewpoint of width and cost of immediacy, we can conclude that the new policy tends to improve, rather than impair, stock liquidity.

On the other hand, if we look at the more complete measure of liquidity represented by the average depth to relative spread (DRS), the new tick size does not significantly affect the total stock liquidity. This finding is different from Purwoto and Tandelilin (2004), where they found that on July 3, 2000 tick size reduction actually diminished the overall stock liquidity. The contradicting results are probably caused by the scope of the two policies. The July 3, 2000 course of action affected all stocks regardless of their prices, while the January 3, 2005 policy affected only stocks between the Rp500 to Rp2000 price band.

Based on these findings, we can conclude that the January 3, 2005 decision made by the JSX board of directors is more selectively implemented, thus it achieves better results in improving stock liquidity. 


\subsection{Order Submission Strategy}

A tick size reduction is likely to decrease relative bid-ask spread. However, if the relative spread is too narrow, the time priority rule becomes less meaningful, and the quote-matcher problem will rise. Quote-matching is a front-running strategy in which quote-matchers try to trade in front of large limit order traders or 'stepping ahead of the book' (Ronen and Weaver 1998). The relative spread therefore is the price that quote-macthers must pay to front-run large traders submitting limit orders.

A narrow percentage spread makes quote-matching strategy more profitable. Therefore, informed traders will defend themselves from quote-matchers by splitting their orders and by switching their trade strategies from limit-order to market-order. Subsequently, these responses will lead to lower market depth.

To analyze the inclination to alternate order submission strategy from limit order to market order, or in the JSX case, to marketable limit order $^{1}$, this study calculate the ratio of marketable limit orders to total orders (MALTO), defined as:

Marketable Limit Oders to Total Orders $(\text { MALTO })_{j, t}=\frac{{\text { Marketable Limit } \text { Order }_{j, t}}_{\text {Total } \text { Order }_{j, t}}}{\text { The }}$

where Marketable Limit Order ${ }_{j, t}$ is the volume (number of shares) of marketable limit order for stock $j$ at day $t$, and Total Order $_{j, t}$ is the volume (number of shares) of total order for stock $j$ at day $t$. Higher MALTO means more orders are submited using marketable limit order. The t-test is used to assess whether MALTO from pre- to post reduction period are significantly different, and the results are given in Table 7.

The average MALTO of the 24 stocks in the sample increases 4.9 per cent from the pre to post reduction period. The t-test strongly rejects the null hypotesis that there is no change in the MALTO average. These results suggest that traders tend to switch from limit orders to market orders after the tick size reduction.

1 A buy (sell) marketable limit order has a limit price that is greater (less) than the best offer (bid) price. Because marketable limit orders are immediately executable, they resemble market orders. 
Table 7

Average marketable limit orders to total orders (MALTO) before and after January 3, 2005 tick size reduction

\begin{tabular}{|c|c|c|}
\hline \multicolumn{2}{|c|}{ Average MALTO } & \multirow{2}{*}{ Average Change } \\
\cline { 1 - 2 } Before $^{\mathrm{a}}$ & After $^{\mathrm{b}}$ & \\
\hline $12.49 \%$ & $17.39 \%$ & $4.90 \% * * *$ \\
\hline
\end{tabular}

a. Average MALTO before tick size reduction (2 November 2004 to 30 December 2004)

b. Average MALTO after tick size reduction (4 January 2005 to 28 February 2005)

*** $\mathrm{t}$-test result is significant at $1 \%$ level

\subsection{Order Size}

To prevent losses to qoute-matchers, limit order traders must control how they expose their orders. Large traders often defend themselves from front-runners or qoute-matchers by not showing the full extent of their interests through their limit orders. They tend to split their orders into smaller parts, or they display only a fraction of total orders. To investigate this, the study calculates the ratio of total buy (sell) order quantity to total number of orders:

Buy (Sell) Order Size ${ }_{j, t}=\frac{\sum_{i=1}^{N O_{j, t}} \text { Buy (Sell) Order Quantity }{ }_{j, t}}{N O_{j, t}}$

Buy (Sell) Order Size $e_{j, t}$ is the of total buy (sell) order quantity to total

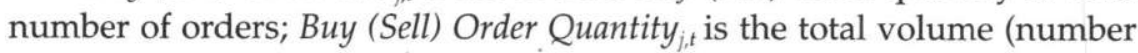
of shares) of buy (sell) orders for stock $j$ at day $t$; and $N O_{j, t}$ is the number of orders for stock $j$ at day $t$. The t-test is then used to test whether the change in average order size from before to after reduction period is significant, and the results are shown in Table 8.

The average Buy Order Size decreases 66,615 shares or 33.3 per cent from before to the after reduction period. The average Sell Order Size decreases 35,467 shares or 21.5 per cent from the pre to post reduction period. The t-test strongly rejects the null hypotesis that there is no 
change in average Order Size. These results suggest that traders tend to split their orders after the tick size reduction.

Table 8

Average buy order size and sell order size, before and after tick size reduction

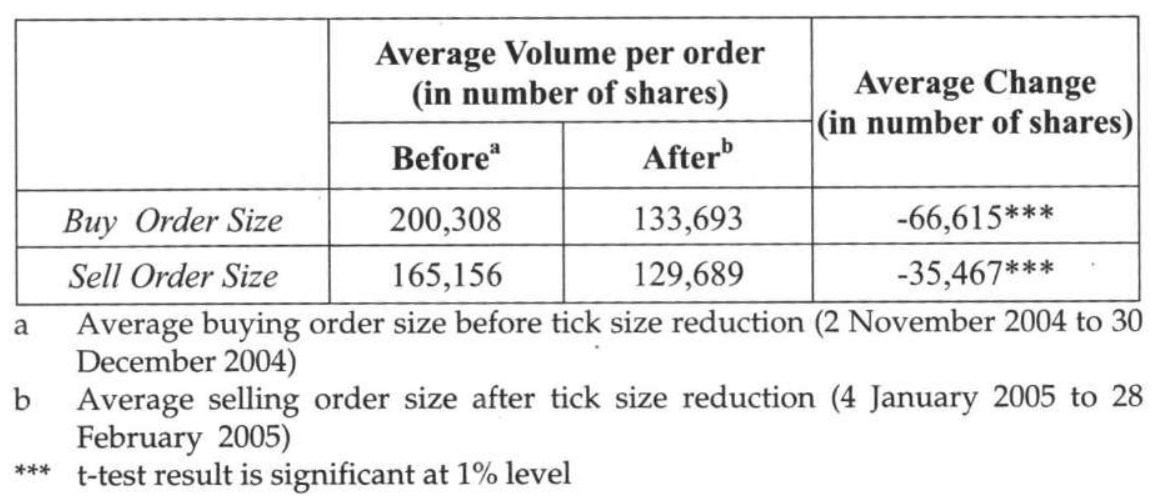

\section{CONCLUDING REMARKS}

This study was triggered by the Jakarta Stock Exchange (JSX) decision on January 3, 2005 to implement a new tick size of Rp10, in addition to the extant three tick sizes of Rp5, Rp25, and Rp50. This new tick affects shares within the Rp500-Rp2000 price range, for they were previously traded with Rp25 tick. The JSX board of directors claims that besides enhancing JSX revenue, the main purpose of adding this new tick size is to increase liquidity, particularly for shares within the aforementioned range.

This study measures liquidity using relative bid-ask spread, bid-ask depth, and the ratio of average depth to relative bid-ask spread. From the width and immediacy aspects, the implementation of the Rp10 tick size improves stock liquidity, since relative bid-ask spreads or the costs of immediacy are significantly lower. On the contrary, from the depth viewpoint, stock liquidity is diminished, because bid and ask depth tumbled significantly. These two results are consistent with the findings of Purwoto and Tandelilin (2004), investigating the impact of the JSX tick size reduction on July 3,2000 .

To resolve the two contradictory results, we use the ratio of average depth to relative spread (DRS). We find that the tick size reduction does not instigate significant change of average DRS, or it does not impair total 
liquidity. This result is different from Purwoto and Tandelilin (2004) since they found significant reduction in DRS after the adoption of a single tick size policy. We deduce that the difference is rooted in the scope of the two events. On January 3, 2005, the new Rp10 tick size was added amid the existing three tick sizes of Rp5, Rp25, Rp50; and this course of action only affected certain stocks between the Rp500 to Rp2000 price range. While, on July 3, 2000, the Rp5 single tick size was applied to all listed stocks regardless of their prices.

Based on these results, we can confirm that the JSX board of directors January 3, 2005 policy improved liquidity, in particular for shares affected by the new tick size. The board managed to reduce the relative bid-ask spreads without demolishing the total liquidity, measured by the ratio of average depth to relative bid-ask spread (DRS). We believe if the JSX selectively implement new tick sizes for illiquid stocks, which are mostly comprised of low price stocks, it will improve their liquidity.

Plummeting relative spreads mean more risks to large limit order traders and informed traders. Our findings show that the tick size reduction causes traders to change their order strategy. With narrower relative spreads, informed traders will likely change their strategy from using limit orders to market orders or marketable-limit orders. This change of strategy is to protect them from parasitic traders, namely quote matchers and front runners.

For the same reason, lower relative spreads also significantly reduce limit order size, because informed traders must control how they expose their orders. Large traders often do not show the full extent of their interests through their limit orders. They are compelled to divide their orders into smaller parts, or they only display some portions of their total orders. Consequently, this strategy will trigger lower bid and ask depth.

\section{REFERENCES}

Ahn, H., Cao, C. and Choe, H., 1996. Tick Size, Spread and Volume. Journal of Financial Intermediation, 5, pp.2-22.

Atmoko, A.B., 2001. Kajian Perubahan Fraksi Harga Saham di Bursa Efek Jakarta. Penelitian, Jakarta: Universitas Indonesia.

Bacidore, J., 1997. The Impact of Decimalization on Market Quality: An Empirical Investigation of the Toronto Stock Exchange. Journal of Financial Intermediation, 6, pp.92-120. 
Bacidore, J., Battalio, R. and Jennings, R., 2003. Order Submission Strategies, Liquidity Supply, and Trading in Pennies on the New York Stock Exchange. Journal of Financial Markets, 6, pp.337-362.

Bessembinder, H., 1997. Endogenous Changes in The Minimum Tick: An Analysis of Nasdaq Securities Trading Near Ten Dollars. (Working Paper) Arizona State University, unpublished.

Bessembinder, H., 2000. Tick Size, and Liquidity:An Analysis of Nasdaq Securities Trading near Ten Dollars. Journal of Financial Intermediation, 9, pp.213-239.

Bourghelle, D. and Declerck, F., 2004, Why Market Should Not Necessarily Reduce The Tick Size. Journal of Banking \& Finance, 28, pp.373-398.

Ekaputra, I.A., 2006. Determinan Intraday Bid-Ask Spread Saham di Bursa Efek Jakarta. Manajemen Usahawan Indonesia, No.5/TH. XXXV, May 2006.

Goldstein, M. and Kavajecz, K., 2000. Eights, Sixteenth, and Market Depth: Changes in Tick Size and Liquidity Provision on NYSE. Journal of Financial Economics, 56, pp.125-149.

Harris, L., 1994. Minimum Price Variation, Discrete Bid-Ask Spreads, and Quotation Sizes. Review of Financial Studies, 7, pp.149-178.

Harris, L., 2003. Trading and Exchanges: Market Microstructure for Practitioners. New York: Oxford University Press.

Lau, S. and McInish, T., 1995. Reducing Tick Size on The Stock Exchange of Singapore. Pasific-Basin Finance Journal, 3, pp.485-496.

Purwoto, L. and Tandelilin, E., 2004. The Impact of Tick Size Reduction on Liquidity. Gadjah Mada International Journal of Business, 6, pp.225-249.

Ronen, T. and Weaver, D.G., 1998. The Effect of Tick Size on Volatility, Trade Behavior, and Market Quality. (Working Paper). 


\title{
In Memoriam
}

\section{Professor Sarbini Sumawinata, 1918 - 2007}

\author{
Thee Kian Wie
}

On Tuesday, 13 March 2007 Professor Sarbini Sumawinata, Professor Emeritus at the Faculty of Economics, University of Indonesia (FEUI), passed away after a long illness In addition to teaching international economics and economic development at FEUI, Professor Sarbini was also the founder of the highly regarded bilingual magazine Business News, where for many years he served as Chairman of the Board.

Born on 20August 1918 in Madiun, where he received his primary and junior high school education, Sabini left for Yogyakarta for his senior high school education at the Algemene Middelbare School (AMS). Upon his graduation from the AMS, Sarbini enrolled at the School of Engineering (Technische Hogeschool, $\mathrm{TH}$ ) to study civil engineering. Sarbini quit his study at the TH after the Japanese occupied Indonesia, since he was reluctant to study at what had become a Japanesesponsored institute.

After Indonesia's proclamation of independence in 1945, Sarbini went to Yogyakarta to resume his engineering studies at the newlyestablished Gadjah Mada University, where he wanted to switch to mechanical engineering. Since there were no mechanical engineers in the Faculty of Engineering, Sarbini's study was stalled. He then joined the Ministry of Economic Affairs as an employee because of his growing interest in economics.

After the Dutch recognition of Indonesia's independence in December 1949, Sarbini left for Jakarta, and in 1951 was sent to Paris as a technical member of the Indonesian delegation to a United Nations conference. Afterwards, with the consent of Wilopo who was then Minister of Economic Affairs, Sarbini went to The Hague, to work at the Netherlands Central Planning Bureau under Professor Tinbergen. who warmly welcomed him. It was at this Bureau where Sarbini had his first exposure to economics. At this Bureau Sarbini studied economic planning, since upon his return to Indonesia he was scheduled to replace the Dutch head of the planning section of the Ministry of Economic Affairs. 
After a one year stint at the Netherlands Central Planning Bureau, Sarbini went to Washington, DC, where he was attached to the Indonesian embassy as a staff member on study assignment (tugas belajar). To this end, Sarbini met with several economists at the World Bank, the International Monetary Fund, the US Department of Agriculture and other offices, to learn more about the problems faced in economic development.

During Sarbini's study assignment in Washington, DC, Sarbini also took some economic courses at The American University. Sarbini's good examination results led an American consultant to the Indonesian embassy to suggest that Sarbini enroll for a degree in economics rather than just take courses. Although Sarbini had no previous formal education in economics, he was allowed to study for a Master's degree in economics at Harvard University, which he was able to finish in one year.

Upon completion of his Master's study, Sarbini had to return to Indonesia immediately to replace the Dutch head of the Central Bureau of Statistics (BPS). Since Sarbini did not have any experience in running a statistical bureau, he requested permission to study how a large, well-run statistical office was managed. Sarbini then went to Ottawa, Canada, to work for three months at the Dominion Bureau of Statistics on a scholarship from the Canadian government. At this Bureau Sarbini learned about the organisational and managerial problems of running a statistical bureau.

Sarbini returned to Indonesia in 1955 to become the first Indonesian head of BPS, a post he held until mid-1965. During this period Sarbini participated in the annual conferences on statistics in Bangkok convened by ECAFE (Economic Commsion for Asia and the Far East), which later was renamed Economic and Social Commision for Asia and the Pacific (ESCAP). Most of the participants were, like Sarbini, new to their job, so participation in these conferences gave Sarbini and the other participants a much better understanding of the problems faced in collecting statistics, including the problems of holding a population census.

During his term in office Sarbini was able to transform the Bureau from a relatively small and centralised office into an agency which could collect statistical data throughout the whole of Indonesia. Preparing to conduct Indonesia first Population Census after independence in 1961, an Agricultural Census, an Industrial Census and the National SocioEconomic Survey (Susenas), Sarbini was able to establish BPS as a nationwide operational organization. This involved the establishment of branch offices of BPS in every province, the Kantor Statistik Propinsi (Provincial Statistical Office). 
During the early 1960s Sarbini faced increasing pressure from the then powerful Indonesian Communist Party (PKI) to resign as head of BPS and as chairman of the Association of Indonesian Economists (ISEI), which he also headed at the time. Although Sarbini resisted pressure from various government ministers to resign voluntarily, he was eventually dismissed as head of BPS in early September 1965. Sarbini's former deputy was subsequently appointed as acting head of BPS. In ISEI Sarbini was also able to prevent the PKI from controlling the organization by supporting a new chairman who was not beholden to the PKI.

Concerned about Indonesia's deteriorating economy, Subandrio, the Deputy First Minister and Minister of Foreign Affairs, in 1963 asked his friend Soedjatmoko for help in formulating a new economic program for Indonesia. Soedjatmoko subsequently consulted Sarbini and a few other economists, all of whom agreed that it would be politically important to accede to Subandrio's request, since it would be a good opportunity to drive a wedge between President Sukarno and the PKI by drawing attention to the country's serious economic problems.

The focus of the economic program which Soedjatmoko, Sarbini and the other economists designed was deconcentration (dekonsentrasi) , which was basically similar to the deregulation concept under the New Order. Hence, the name Economic Declaration (Deklarasi Ekonomi), better known under its acronym Dekon, referred to the main focus of the program. The Dekon was mainly a combination of Soedjatmoko's and Sarbini's views, with Soedjatmoko dealing with the political and social issues.

Subandrio was very happy with the draft, but the PKI was able to undermine the thrust of Dekon by insisting to include an opening statement that Indonesia's national struggle consistred of several phases, and that Indonesia at the time (1963) was going through the nationaldemocratic phase of the people's struggle, during which the focus should be on anti-imperialism. In this way the thrust of the original Dekon on deconcentration was completely erased..

At the beginning of the New Order General Soeharto established a Team of Economic Experts, headed by Professor Widjojo Nitisastro and a Team of Political Experts headed by Professor Sarbini. At the Second Army Seminar of 1966 Sarbini and Soedjatmoko presented a joint paper on 'The Problem of Political Stabilisation' in which the danger of creeping militarism, the need for an equal partnership between the military and civilians, and the need for press freedom, was mentioned. Not surprisingly, this paper was not well received by the military..

When Soeharto was officially installed as Indonesia's second president in 1968, he disbanded both the economic and political teams. 
While the former members of the economic team (Widjojo, Ali Wardhana, Moh. Sadli, Subroto and Emil Salim) were subsequently appointed as cabinet ministers, Sarbini was offered the ambassadorship in Washington, DC, an offer he declined.

When in January 1974 anti-Japanese riots broke out in Jakarta, Soeharto's intelligence agents looked for scapegoats and accused former members of Masyumi and the PSI (the Indonesian Socialist Party) which had been banned by Sukarno, of fomenting these riots. A few former members of PSI, including Sarbini and Subadio Sastrosatomo and student activists, including Sjahrir and Hariman Siregar, were arrested and put in jail. Sarbini himself spent two-and-a half years in jail without any trial..

Upon his release, Sarbini resumed his work with 'Business News', but continued to elaborate in various writings on the need to establish a 'people's economy' (ekonomi kerakyatan) in which industrial strategy would have to focus on establishing rural industries to raise the welfare of the rural population.

Although Sarbini was not able to realize his ideals, his ideals live on, particularly among young people disaffected with the current economic conditions of high unemployment and poverty and widening economic disparities between rich and poor which are aggravated by widespread corruption.

\section{REFERENCES:}

Sarbini Sumawinata, Recollections of My Career, Bulletin of Indonesian Economic Studies, Vol. 28, no. 2 (August), pp. 43-53; Reprinted in Thee Kian Wie (editor), Recollections - The Indonesian Economy, 1950s - 1990s, Institute of Southeast Asian Studies, Singapore, 2003, pp. $103-17$.

Rosihan Anwar, 'In Memoriam' Prof. Sarbini, KOMPAS, 14 March 2007.

Emil Salim, In Memoriam: Berpulangnya Pejuang Kerakyatan, KOMPAS, 15 March 2007.

Moh. Sadli, Pendiri Business News Meninggal, Business News, 16 March 2007. 


\section{Contributor of The Issue}

Akhmad Rizal Shidiq

Basharat Ahmad

Esta Lestari

Hermanto Siregar

Irwan Adi Ekaputra

Thee Kian Wie

Tri Widodo

Yulismi
: Researcher Institute for Economic and Social Research (LPEM)

: Financial researcher PT. Bank Mandiri (Persero), Tbk, Jakarta basharat.ahmad@bankmandiri.co.id

: Researcher Economic Research Centre, Indonesia Institute of Sciences (P2E-LIPI)

: Lecturer in economics, and Academic Director of Graduate Program of Management \& Business Bogor Institute for Agriculture (IPB)

: Lecturer Faculty of Economics, University of Indonesia. MM-UI iae@mmui.edu

: Researcher Economic Research Centre, Indonesia Institute of Sciences (P2E-LIPI)

: International Office, Hiroshima University of Economics, 37-1 Gion 5-Chome, ui55t003@pcnet.hue.ac.jp; kociwid@yahoo.com

: Lecturer Faculty of Agriculture Universitas Jambi 